\title{
Curcuma mangga Val. Extract as Antidiabetic Agent in 3T3-L1 Adipocyte Cells
}

\author{
Dwiyati Pujimulyani ${ }^{1}$, Wisnu Adi Yulianto ${ }^{1}$, Astuti Setyowati ${ }^{1}$, Rizal Rizal ${ }^{2}$, Rismawati Laila Qodariah ${ }^{2}$, \\ Zakiyatul Khoiriyah², Annisa Arlisyah², Wahyu Widowati ${ }^{3}$ \\ ${ }^{1}$ Faculty of Agroindustry, University of Mercu Buana Yogyakarta, DI Yogyakarta, Indonesia \\ ${ }^{2}$ Biomolecular and Biomedical Research Center, Aretha Medika Utama, Bandung, Indonesia \\ ${ }^{3}$ Medical Research Center, Faculty of Medicine, Maranatha Christian University, Bandung, Indonesia
}

Background: With the increase of diabetes mellitus (DM) prevalence, natural product emerged as complementary source on the development of new drug for this disease. White saffron (Curcuma mangga Val.) is a widely available plant found in Indonesia which often used traditionally as medicine for various ailment. Unfortunately scientific evidence of its antidiabetic activity has not been described very well. Present study was trying to evaluate the antidiabetic potential of white saffron based on the change of lipid accumulation.

Materials and Methods: Cells viability assay was done using 3-(4,5-dimethylthiazol-2-yl)-5-(3-carboxymethoxyphenyl)2-(4-sulfophenyl)-2H-tetrazolium (MTS) reagent to determine the safe concentrations of $C$. mangga Val. extract and its fractions including hexane, ethyl acetate, butanol, ethanol, water fractions and curcumol for the further assay. The preadipocyte cells (3T3-L1) were grown and differentiated into adipocyte cells using 3-isobutyl-1-methylxanthine (IBMX), dexamethasone and insulin. The adipocyte cells were treated with $C$. mangga Val. extract (CME) (the safest fraction at all concentrations) for $24 \mathrm{~h}$. Oil red $\mathrm{O}$ staining was used to measure the lipid accumulation in adipocyte cells.

Results: The CME was not toxic and able to decrease the lipid droplets of the 3T3-L1 adipocyte cells.

Conclusion: The CME has potential antidiabetic activity due to ability to decrease the lipid droplet without disturbing the viability of the 3T3-L1 adipocyte cells.

Keywords: white saffron, Curcuma mangga Val., antidiabetic

\section{Introduction}

The increase of life quality afflicted the increase of diabetes mellitus (DM) prevalence in many countries throughout the world. The World Health Organization (WHO) predicts by 2030 people with DM will reach up to 370 million in the world and 79.5 million people in Southeast Asia. Along with ever increasing prevalence, improvement for drug and treatment for DM is needed. Several studies showed that natural products has an important role for treating DM and its complications. For example, guanidine isolated from Galega officinalis was developed into metformin. ${ }^{1}$ 
Metformin is an antidiabetic drug commonly used for the treatment of type II DM (T2DM) and obesity. Curcumin extracted from rhizome of the plant Curcuma longa has been used for treating DM as described in traditional chinese medicine. ${ }^{2}$ Thus natural product served as complementary source on the development of new drug for DM.

White saffron (Curcuma mangga) is an annual shrub plant belong to ginger family (Zingiberaceae). White saffron is widely available in Indonesia and often used as traditional medicine for numbers of disease. ${ }^{3}$ These activity due to the phytochemical compound found in white saffron including curcumin, tannin, sugar, volatile oil and flavonoid ${ }^{4}$, phenolic ${ }^{5}$, querscetin-3-rutinoside, quersetin ${ }^{6}$, and curcumol ${ }^{7}$. Curcumin and its derivates is a major compound of Zingiberace family, including white saffron. In animal study, curcumol and curcumin was able to lower blood glucose level effectively. ${ }^{8,9}$ Previous study showed that C. mangga Val. extract and its fractions has a potent antioxidant and glucosidase inhibitory activity. ${ }^{10}$ As both biological activities played important role in DM, white saffron might have a potential antidiabetic activity. Unfortunately further scientific evidence of antidiabetic activity of white saffron extract and its fractions has not been described very well.

The excessive storage of lipid recently has shown to be a cause of various diseases including T2DM, cardiovascular disease and atherosclerosis. ${ }^{11}$ Previous study found a strong correlation between consumption of product that increase lipid accumulation and DM in Japanese women and men. ${ }^{12}$ Increased accumulation of lipid is related with development of insulin resistance, peroxidation of lipid and inflammation in patients with T2DM. ${ }^{13}$ As reducing ectopic lipid accumulation has been shown to reverse insulin resistance and obesity.

Thus, present study was trying to evaluate the antidiabetic potential of white saffron based on the change of lipid accumulation. Two important aspects were measured and analysed, namely the effect of the extract to the vialibility of the cell, and the lipid droplet accumulation of 3T3-L1 adipocyte cells.

\section{Materials and methods}

\section{Chemicals and Reagents}

Ethanol, hexane, ethyl acetate, butanol, curcumol, dexamethasone, metformin, insulin, oil red $\mathrm{O}$ and other chemicals used in present study was purchased from
Merck (Darmstadt, Germany). Aquadest used in the study was obtained using a Milli-Q Water Purification System (Catalogue \#ZRQSVP3000, Merck, Molsheim, France).

\section{The Plant Material}

C. mangga Val. plants were obtained from the plantation in Bantul, Yogyakarta, Indonesia.The plant material was then identified by the herbarium staff of Biology Department, School of Life Sciences and Technology, Bandung Institute of Technology, Bandung, Indonesia.

\section{Extract and Fraction Preparation}

The extraction and fractionation were processed using method previously described. ${ }^{10,14}$ The maceration process was done using ethanol since the major compound of C. mangga Val. were soluble in ethanol. C. mangga Val. rhizomes was cleaned, dried, and ground into fine powder. After dried C. mangga Val. powder were then soaked in $70 \%$ $(1500 \mathrm{~mL})$ distilled ethanol and filtered until colorless filtrate was gained, every $24 \mathrm{~h}$. Briefly, the filtrate was evaporated to obtain C. mangga Val. extract (CME) and stored at $-20^{\circ} \mathrm{C}$. CME was mixed thoroughly with aquadest (1:4) until the mixture is homogenous. The mixture was then fractionated in hexane and water; ethyl acetate and water; and butanol and water (1:1). The fractionation replicated 3-4 times.

\section{Viability Assay}

The 3T3-L1 cells (Catalogue \#CL173, ATCC, Manassas Historic District, USA) used in present study were acquired form Aretha Medika Utama, Bimolecular and Biomedical Research Center, Bandung, Indonesia. The 3T3-L1 cells were seeded and grown in Dulbecco's Modified Eagle Medium (DMEM) (Catalogue \#11995065, Gibco, Massachusetts, USA) supplemented with 10\% Fetal Bovine Serum (FBS) (Catalogue \#26140079, Gibco) 1\% Antibiotic/Antimycotic (ABAM) (Catalogue \#15240-062, Gibco) at $37^{\circ} \mathrm{C}, 5 \% \mathrm{CO}_{2}$. 3-(4,5-dimethylthiazol-2-yl)-5-(3carboxymethoxyphenyl-2)-4-sulfophenyl-2H-tetrazolium (MTS) assay was performed to determine viability assay in order to find out the safe and nontoxic concentration of CME and curcumol for further assays. The 3T3-L1 cells at density $5 \times 10^{3}$ cells per well were plated in 96 well-plate containing growth medium and incubated for $24 \mathrm{~h}$ at $37^{\circ} \mathrm{C}, 5 \% \mathrm{CO}_{2}$. Then, the growth medium was discarded and added with $90 \mu \mathrm{L}$ fresh medium and $10 \mu \mathrm{L}$ various concentrations of fraction of CME, ethanol, hexane, ethyl acetate, butanol, water fraction and curcumol $(6.25,12.5,25,50,100$ and 200 
$\mu \mathrm{g} / \mathrm{mL}$, respectively) into the cells and incubated for $24 \mathrm{~h}$. Next, MTS was added to each well $20 \mu \mathrm{L}$ and the plate was incubated in $5 \% \mathrm{CO}_{2}$ at $37^{\circ} \mathrm{C}$ for $3 \mathrm{~h}$. The absorbance was measured at $490 \mathrm{~nm}$ using a Multiskan ${ }^{\mathrm{TM}}$ GO Microplate Spectrophotometer (Catalogue \#N12391, Thermo Scientific, Massachusetts, USA). ${ }^{14-17}$

\section{T3-L1 Adipogenesis Induction}

The 3T3-L1 cells were cultured until reaching $60-70 \%$ confluency, then the medium was replaced by initiation medium (DMEM containing FBS 10\%, IBMX (1:1000) (Catalogue \#90355, Sigma-Aldrich, St. Louis, USA), dexamethasone (1:10000) (Catalogue \#90357, SigmaAldrich), $1 \%$ ABAM and incubated for $48 \mathrm{~h}$ at $37^{\circ} \mathrm{C}, 5 \%$ $\mathrm{CO}_{2}$. Progression medium DMEM supplemented with FBS 10\% and insulin (1:1000) (Catalogue \#90356, SigmaAldrich), 1\% ABAM was then replaced the initiation
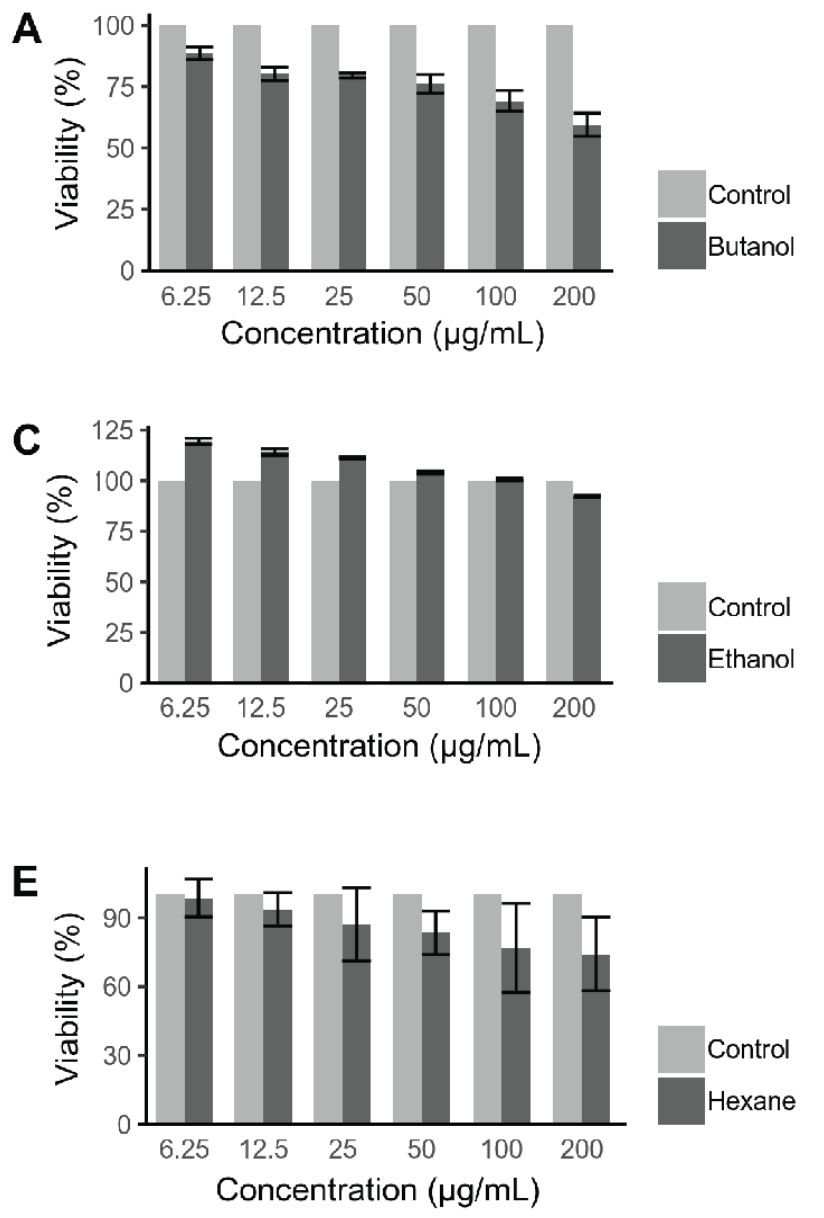

medium and culture was incubated for $48 \mathrm{~h}$ at $37^{\circ} \mathrm{C}, 5 \% \mathrm{CO}_{2}$. Maintenance medium (DMEM supplemented with 10\% calf serum (CS) (Catalogue \#S0400-500, Biowest, Nuaillé, France) was then replaced previous medium and incubated again for $4-5$ days at $37^{\circ} \mathrm{C}, 5 \% \mathrm{CO}_{2}$. After induction, on the fifth day, medium was replaced once again with DMEM supplemented with $10 \%$ FBS and 1\% ABAM. ${ }^{17-19}$

\section{Measurement of Lipid Accumulation}

Measurement of lipid accumulation was done using Adipogenesis Assay Kit (Catalogue \#ECM950, Merck). Differentiated cells were treated with of CME and curcumol (50 and $10 \mu \mathrm{g} / \mathrm{mL})$, metformin and insulin $(100 \mu \mathrm{M})$, then incubated for $24 \mathrm{~h}$.

The cells was washed with PBS and stained using oilred O (Catalogue \#90358, Merck) and incubated for 15-30 min. The excess dye was removed and the cells were rinsed
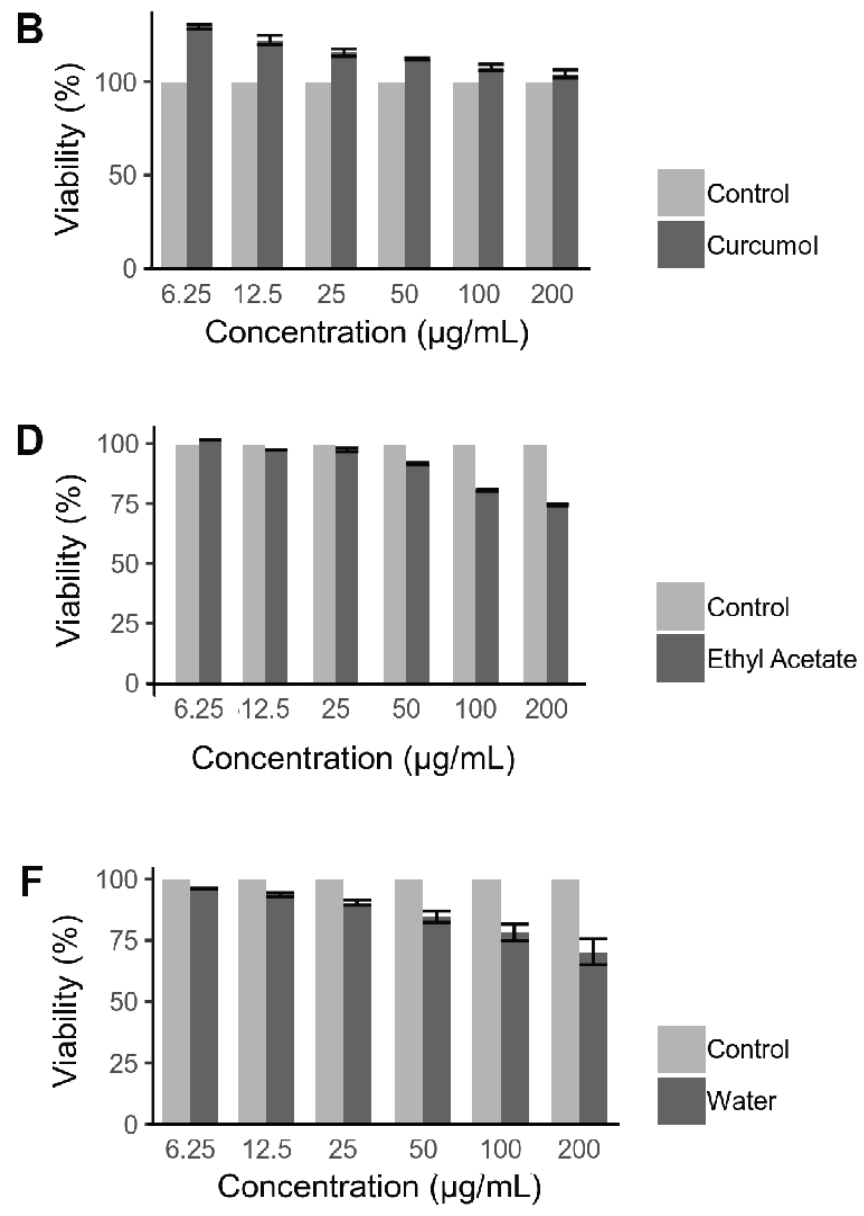

Figure 1. The 3T3-L1 cells viability. Cytotoxic assay of CME and its fractions (hexane, ethyl acetate, butanol and water fraction), ethanol extract using curcumol as comparison on 3T3-L1 cells. A: butanol fraction; B: curcumol; C: ethanol; D: ethyl acetate fraction; E: hexane fraction; F: water fraction. The experiment was performed in triplicate $(\mathrm{n}=3)$. 

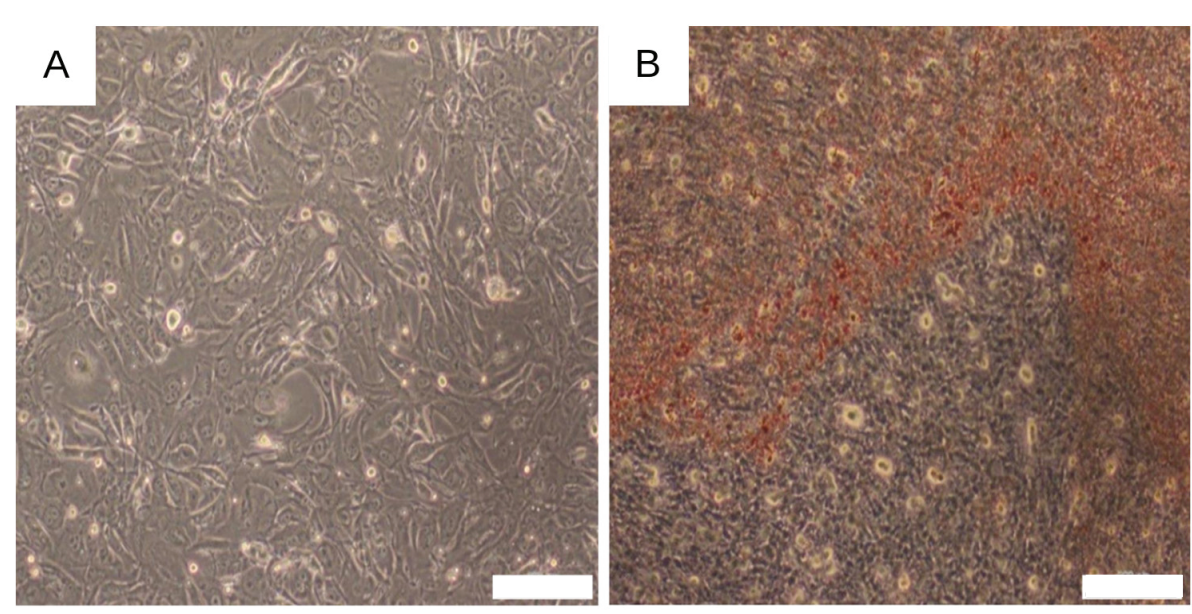

Figure 2. Morphology of 3T3L1 cells. A: 3T3-L1 preadipocyte cells; B: 3T3-L1 adipocyte cells staining with oil red $\mathrm{O}$. White bar: $500 \mu \mathrm{m}$. using Wash Solution (Catalogue \#90360, Merck). Using inverted light Olympus microscope (Olympus Inverted Microscope CKX41-F32FL, Olympus, Tokyo, Japan) the stained cells were observed. Lipid-bound oil red o was then extracted using dye extraction kit (Catalogue \#90359, Merck) and incubated on orbital shaker (Catalogue \#S0600, Labnet, New York, USA) for 15-30 min. Extracted lipid-bound oil red $\mathrm{O}$ was transferred into 96-well plate quantified based on absorbance read at $490 \mathrm{~nm}$ (Multiskan ${ }^{\mathrm{TM}}$ GO Microplate Spectrophotometer). ${ }^{17-20}$

\section{Results}

\section{The Effect of The CME on The Viability of The 3T3-L1 Adipocyte Cells}

Cytotoxic assay of C. mangga Val. on 3T3-L1 cell lines showed that the inhibition rate was low except in the butanol fraction. Butanol fraction was toxic at all test concentrations $(6.25-200 \mu \mathrm{g} / \mathrm{mL})$. This was indicated by cell viability which was lower than $90.0 \%$. The order of the safest concentration of $C$. mangga Val. extract on 3T3-L1 cell line were curcumol as comparison, ethanol exctract, ethyl acetate fraction, water fraction and hexane fraction (6.25-200 $\mu \mathrm{g} / \mathrm{mL})$. Thus, CME was recommended to be selected for further studies because it was not toxic at all levels of concentration (Figure 1).

\section{Adipogenesis Induction}

The 3T3-L1 cells changed their morphology after the cells were cultured in initiation and progression medium for 4 days and maintained for 8 days. The initial morphology as pre-adipocyte cells was fibroblastic-like cells and they changed into adipocyte-like cells with intracellular lipid droplet (Figure 2).

\section{The Effect of CME on The Lipid Droplet Accumulation}

Based on oil red $\mathrm{O}$ staining, control insulin resulted in more lipid droplets than control non-insulin (negative control) and metformin. CME produced a lower lipid droplet

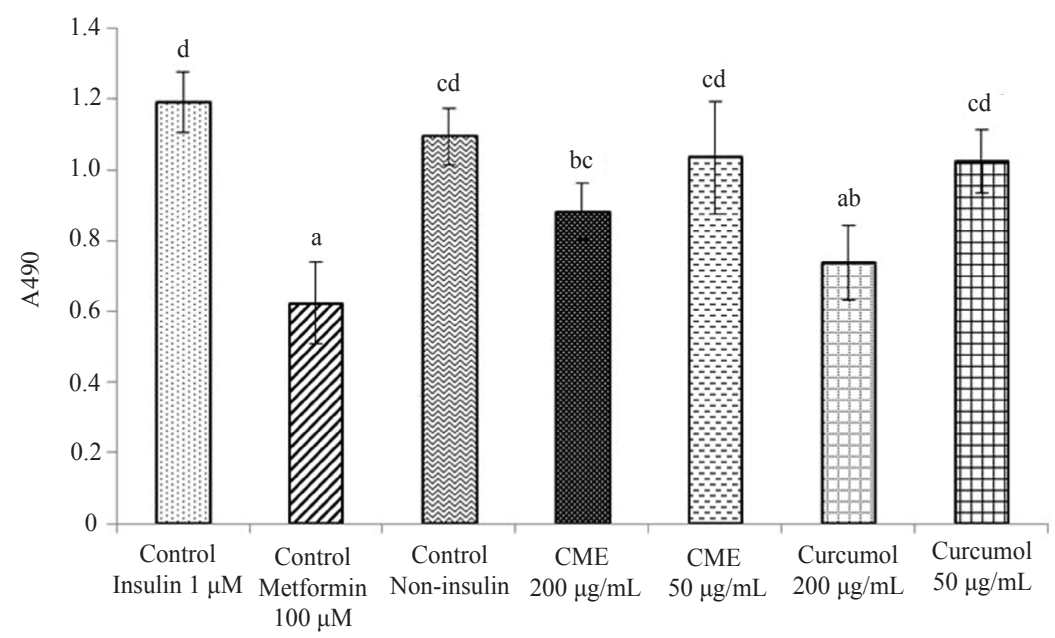

Figure 3. Lipid accumulation in 3T3L1 adypocytes. Data are presented as mean \pm standard deviation. Different supercript letters (a,ab,bc,cd,d) show significant difference $(p<0.05)$ among treatments. The data was analyzed with Anova and Duncan pos hoc test. 
than control insulin but higher compared to curcumol and metformin. CME with a concentration of $50 \mathrm{~g} / \mathrm{mL}$ produced a higher lipid droplet than $200 \mathrm{~g} / \mathrm{mL}$ of CME. The CME decreased lipid accumulation as shown with lower absorbance (0.8822 and 1.0350) compared to insulin controls at 50 and $200 \mu \mathrm{g} / \mathrm{mL}$ respectively through the quantification method of oil red $\mathrm{O}$ staining (Figure 3). Lipid accumulation can be seen in Figure 4.
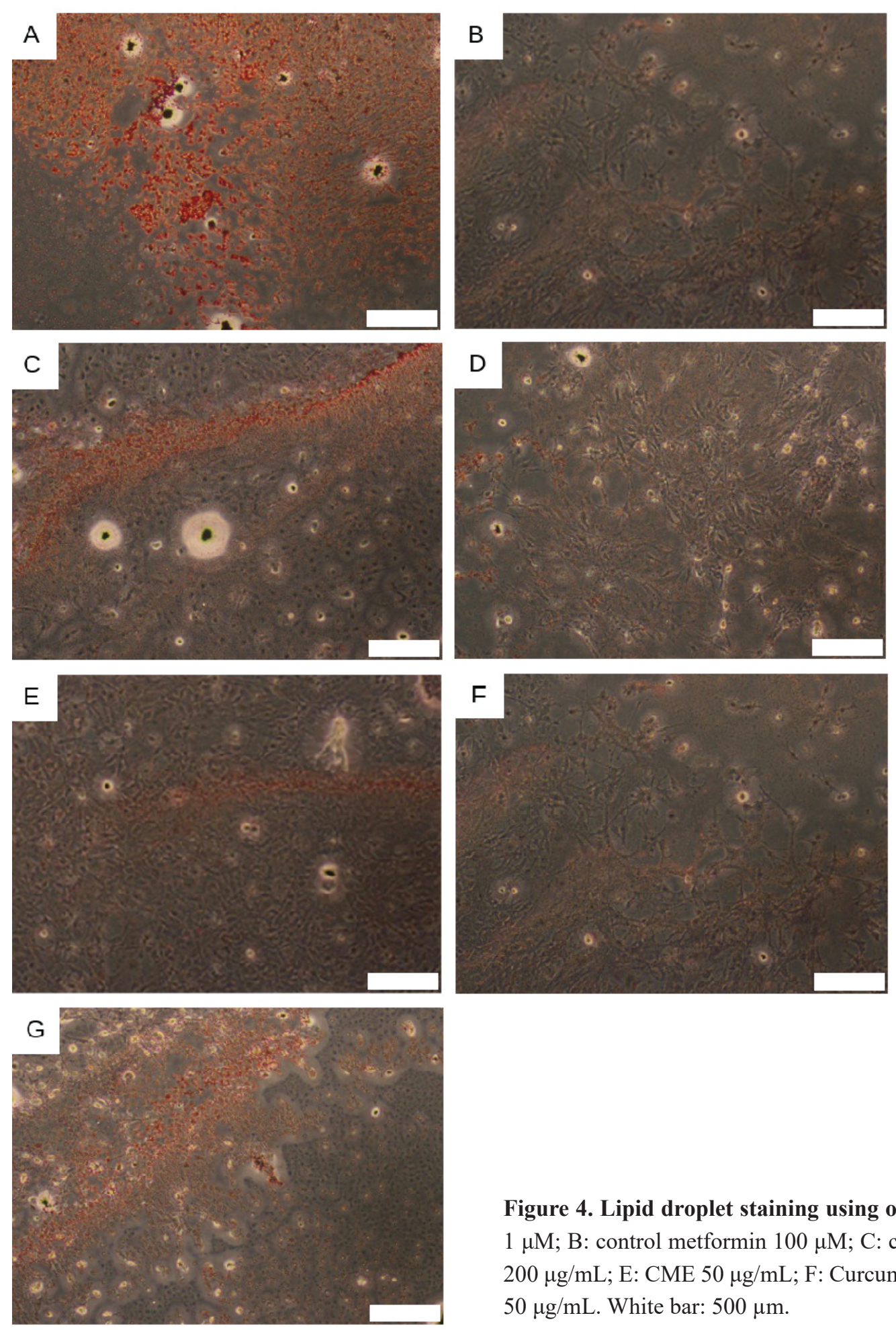

Figure 4. Lipid droplet staining using oil red $\mathrm{O}$. A: control insulin $1 \mu \mathrm{M}$; B: control metformin $100 \mu \mathrm{M}$; C: control non-insulin; D: CME $200 \mu \mathrm{g} / \mathrm{mL}$; E: CME $50 \mu \mathrm{g} / \mathrm{mL}$; F: Curcumol $200 \mu \mathrm{g} / \mathrm{mL}$; G: curcumol $50 \mu \mathrm{g} / \mathrm{mL}$. White bar: $500 \mu \mathrm{m}$. 


\section{Discussion}

DM is one of leading causes of death in Southeast Asia and the Western Pacific based on World Health Organization (WHO) report. ${ }^{21}$ Current medication options for diabetes treatment have non-negligible side effects, are relatively limited and must often be prescribed in combination. ${ }^{22}$ The use of natural products and alternative approaches to existing medications are growing in popularity. The natural compounds of $C$. mangga Val. were believed to have antidiabetic activity. Previous research has been succesfully fractionated C. mangga Val. and evaluated its antioxidant acitivity. ${ }^{10}$ In present study the safe fraction concentration toward 3T3-L1 cells was evalutated. The results showed that CME was the safest fraction at all concentrations, thus CME was chosen for further assay. In line with previous research the CME at dose of $400 \mathrm{mg} / \mathrm{kg}$ bw did not showed any renal cell damage. ${ }^{23}$ Another study also reported that the CME did not induce significant short-term toxicity. ${ }^{24}$

3T3-L1 cells had differentiated into adipocyte cells through the process of adipogenesis. Adipogenesis is conversion of pre-adipocyte cell into mature adipocyte. ${ }^{25}$ Adipocyte cells were characterized by the presence of droplet lipids shaped like grapes in the cytoplasm. ${ }^{26}$ 3T3-L1 cells have a fibroblast-like morphology, but under appropriate conditions the cells differentiate into an adipocyte-like phenotype. The differentiation process of 3T3-L1 cells in adipocyte-like cells was characterized by increased synthesis and accumulation of triglycerides. Accumulation of triglycerides play major role in development of DM. Thus differentiated 3T3-L1 cells is as suitable model for screening antidiabetic compound.

The 3T3-L1 cells that have differentiated into adipocyte cells were then treated using CME, metformin, insulin and non-insulin as control. Furthermore, 3T3-L1 cell line was tested using oil red $\mathrm{O}$ to see the accumulation of lipid droplet. Oil red $\mathrm{O}$ staining is used to quantify adipose and triglycerides conversion and loss of lipids in decellularized tissue. ${ }^{27}$ The results showed that insulin and non-insulin controls resulted in more lipid droplets than control metformin. Metformin is a well-known 5' AMPactivated protein kinase (AMPK) activator. ${ }^{28}$ Activated AMPK upregulates catabolic processes to generate adenosine triphosphate (ATP) and suppresses energy consuming pathways. ${ }^{29}$ AMPK was able to induce glucose uptake from the bloodstream and attenuate gluconeogenesis supression..$^{30}$ Therefore, the blood sugar will be uptake into the cell and converted into energy. This indicates that in the presence of metformin, lipid droplets will not be formed because blood sugar converted to energy.

3T3-L1 adipocyte cells treated with CME and curcumol as a comparison showed that lipid droplets decreased (Figure 3), which was in line with previous study in which showed that curcumin compounds can inhibit the formation of lipid droplets. ${ }^{31}$ The curcumin decreased the formation of intracellular lipid droplets by inhibiting gene regulation and adiponectin. ${ }^{32}$ Lipid droplet formation was influenced by several factors, the presence of peroxisome proliferator-activated receptor (PPAR)- $\gamma$, glucose transporter type 4 (GLUT4) as glucose transporter and also external stimulus, such as insulin or natural extract. Previous study suggested that curcumin compounds downregulated PPAR- $\gamma$ regulation, leading to inhibited lipid droplet formation..$^{28}$ Thus the anti-lipid droplet formation activity of CME might be regulated through the inhibition of PPAR- $\gamma$ functions. ${ }^{31}$ Further study is required to address this possible mechanisms.

\section{Conclusion}

This study showed that CME is able to decrease the lipid droplet formation in 3T3-L1 Adipocyte Cells without interfering the viability of the cells. Therefore, CME is a potential herbal material for antidiabetic activity. Further study is required to determine possible mechanisms underlies the activity found in present study.

\section{Acknowledgements}

This research was funded by the Indonesian Ministry of Research, Technology and Higher Education for 2018 research grant (fundamental research) No. 109/SP2H/LT/ DRPM/2018. This research was also supported by Aretha Medika Utama Biomolecular and Biomedical Research Center, Bandung, Indonesia for the research methodology and laboratory facilities. We are thankful to Ni Luh Wisma Eka Yanti, Hanna Sari W. Kusuma, Ubaydillah Zedd Munshy, Satrio Haryo Benowo Wibowo, Wahyu Setia Widodo from Aretha Medika Utama Biomolecular and Biomedical Research Center, Bandung, Indonesia for their valuable assistance.

\section{References}

1. Spoor DCA, Martineau LC, Leduc C, Benhaddou-Andaloussi A, Meddah B, Harris C, et al. Selected plant species from the Cree pharmacopoeia of northern Quebec possess antidiabetic potential. Can J Physiol Pharmacol. 2006; 84(8-9): 847-58. 
2. Agrawal R, Sethiya NK, Mishra SH. Antidiabetic activity of alkaloids of Aerva lanata roots on streptozotocin-nicotinamide induced typeII diabetes in rats. Pharm Biol. 2013; 51(5): 635-42.

3. Srirod S, Tewtrakul S. Anti-inflammatory and wound healing effects of cream containing Curcuma mangga extract. J Ethnopharmacol. 2019; 238: 111828. doi: 10.1016/j.jep.2019.111828.

4. ASEAN Secretariat. ASEAN Herbal and Medicinal Plants. Jakarta: ASEAN Secretariat; 2010.

5. Pujimulyani D, Raharjo S, Marsono Y, Santoso U. The effects of blanching treatment on the radical scavenging activity of white saffron (Curcuma mangga Val.). Int Food Res J. 2010; 17: 615-21.

6. Pujimulyani D, Raharjo S, Marsono Y, Santoso U. The phenolic substances and antioxidant activity of white saffron (Curcuma mangga Val.) as affected by blanching methods. Int J Nutr Food Eng. 2013; 7(10): 947-50.

7. Afzal A, Oriqat G, Akram Khan M, Jose J, Afzal M. Chemistry and biochemistry of terpenoids from curcuma and related species. J Biol Act Prod from Nat. 2013; 3(1): 1-55. doi: 10.1080/22311866.2013.782757.

8. Goel A, Kunnumakkara AB, Aggarwal BB. Curcumin as "curecumin": from kitchen to clinic. Biochem Pharmacol. 2008; 75(4): 787-809.

9. Shehzad A, Ha T, Subhan F, Lee YS. New mechanisms and the anti-inflammatory role of curcumin in obesity and obesity-related metabolic diseases. Eur J Nutr. 2011; 50(3): 151-61.

10. Pujimulyani D, Yulianto WA, Setyowati A, Arumwardana S, Rizal R. Antidiabetic and antioxidant potential of Curcuma mangga Val. extract and fractions. Asian J Agric Biol. 2018; 6(2): 162-8.

11. Wong CP, Kaneda T, Morita H. Plant natural products as an antilipid droplets accumulation agent. J Nat Med. 2014; 68(2): 253-66.

12. Wakabayashi I, Daimon T. A strong association between lipid accumulation product and diabetes mellitus in japanese women and men. J Atheroscler Thromb. 2014; 21(3): 282-8.

13. Mirmiran P, Bahadoran Z, Azizi F. Lipid accumulation product is associated with insulin resistance, lipid peroxidation, and systemic inflammation in type 2 diabetic patients. Endocrinol Metab. 2014; 29(4): 443. doi: 10.3803/EnM.2014.29.4.443.

14. Widowati W, Rani AP, Hamzah RA, Arumwardana S, Afifah E, Kusuma HSW, et al. Antioxidant and antiaging assays of Hibiscus sabdariffa extract and its compounds. Nat Prod Sci. 2017; 23(3): 192. doi: 10.20307/nps.2017.23.3.192.

15. Widowati W, Widyanto RM, Husin W, Ratnawati H, Laksmitawati $\mathrm{DR}$, Setiawan B, et al. Green tea extract protects endothelial progenitor cells from oxidative insult through reduction of intracellular reactive oxygen species activity. Iran J Basic Med Sci. 2014; 17(9): 702-9.

16. Sandhiutami NMD, Moordiani M, Laksmitawati DR, Fauziah N, Maesaroh M, Widowati W. In vitro assesment of anti-inflammatory activities of coumarin and Indonesian cassia extract in RAW264.7 murine macrophage cell line. Iran J Basic Med Sci. 2017; 20(1): 99-106.

17. Widowati W, Darsono L, Suherman J, Afifah A, Rizal R, Arinta Y, et al. Mangosteen peel extract (Garcinia mangostana L.) and its constituents to lower lipid content on adipogenesis cells model (3T3-L1). J Nat Remedies. 2018; 18(2): 41-8.

18. Hidayat M, Soeng S, Prahastuti S, Erawijantari P, Widowati W. Inhibitory potential of ethanol extract of detam 1 soybean (Glycine max) seed and jati belanda (Guazuma ulmifolia) leaves on adipogenesis and obesity models in 3T3-L1 cell line. J Sci Res Rep. 2015; 6(4): 304-12.

19. Hidayat M, Prahastuti S, Fauziah N, Maesaroh M, Balqis B, Widowati W. Modulation of adipogenesis-related gene expression by ethanol extracts of Detam 1 soybean and Jati belanda leaf in 3T3-L1 cells. Bangladesh J Pharmacol. 2016; 11(3): 697. doi: 10.3329/bjp. v11i3.26471.

20. Mutai E, Sunkara R, Vizcarra J, Walker LT, Verghese M. Antioxidant, enzyme inhibitory and anti-obesity potential of sorrel calyx extracts in 3T3-L1 adipocytes. Food Nutr Sci. 2015; 6(5): 452-65.

21. Tiwari AK, Madhusudanarao J. Diabetes mellitus and multiple therapeutic approaches of phytochemicals: Present status and future prospects. Curr Sci. 2002; 28(1): 30-8.

22. Cheng AYY. Oral antihyperglycemic therapy for type 2 diabetes mellitus. Can Med Assoc J. 2005; 172(2): 213-26.

23. Rosita R, Yuandani Y, Marianne M. Nephroprotective activity of ethanol extract of Curcuma mangga val. in paracetamol-induced male mice. Asian J Pharm Clin Res. 2018; 11(13): 126. doi: 10.22159/ajpcr.2018.v11s1.26585.

24. Yuandani Y, Suwarso E. Immunomodulatory effects of ethanol extract of Curcuma mangga rhizomes in mice. Asian J Pharm Clin Res. 2017; 10(9): 148. doi: 10.22159/ajpcr.2017.v10i9.18398.

25. Kim JS, Lee SG, Kang YJ, Kwon TK, Nam JO. Kahweol inhibits adipogenesis of 3T3-L1 adipocytes through downregulation of PPAR $\gamma$. Nat Prod Res. 2018; 32(10): 1216-9.

26. Paar M, Jüngst C, Steiner NA, Magnes C, Sinner F, Kolb D, et al. Remodeling of lipid droplets during lipolysis and growth in adipocytes. J Biol Chem . 2012; 287(14): 11164-73.

27. Rizzatti V, Boschi F, Pedrotti M, Zoico E, Sbarbati A, Zamboni M. Lipid droplets characterization in adipocyte differentiated 3T3-L1 cells: size and optical density distribution. Eur J Histochem. 2013; 57(3): 24. doi: 10.4081/ejh.2013.e24.

28. Yen HF, Hsieh CT, Hsieh TJ, Chang FR, Wang CK. In vitro antidiabetic effect and chemical component analysis of 29 essential oils products. J Food Drug Anal. 2015; 23(1): 124-9.

29. Gaidhu MP, Ceddia RB. Remodeling glucose and lipid metabolism through AMPK activation: relevance for treating obesity and type 2 diabetes. Clin Lipidol. 2009; 4(4): 465-77.

30. Zhang D, Fu M, Gao SH, Liu JL. Curcumin and diabetes: a systematic review. Evidence-Based Complement Altern Med. 2013; 2013: 636053. doi: 10.1155/2013/636053.

31. Ejaz A, Wu D, Kwan P, Meydani M. Curcumin inhibits adipogenesis in 3T3-L1 adipocytes and angiogenesis and obesity in C57/BL mice. J Nutr. 2009; 139(5): 919-25.

32. Feng S, Reuss L, Wang Y. Potential of natural products in the inhibition of adipogenesis through regulation of PPAR $\gamma$ expression and/or its transcriptional activity. Molecules. 2016; 21(10): 1278. doi: 10.3390/molecules21101278.

33. Yang H, Du Z, Wang W, Song M, Sanidad K, Sukamtoh E, et al. Structure-activity relationship of curcumin: role of the methoxy group in anti-inflammatory and anticolitis effects of curcumin. J Agric Food Chem. 2017; 65(22): 4509-15.

34. Sakuma S, Sumida M, Endoh Y, Kurita A, Yamaguchi A, Watanabe $\mathrm{T}$, et al. Curcumin inhibits adipogenesis induced by benzyl butyl phthalate in 3T3-L1 cells. Toxicol Appl Pharmacol. 2017; 329: 158-64. 